\title{
Halting Forest Encroachment in Terai: What Role for Community Forestry?
}

\author{
Prabin Bhusal ${ }^{1}$, Naya Sharma Paudel ${ }^{2}$, Anukram Adbikary², \\ Jisan Karki ${ }^{1}$ and Kamal Bhandari ${ }^{2}$ \\ ${ }^{1}$ Institute of Forestry, Pokhara Campus, Tribhuvan University and \\ ${ }^{2}$ ForestAction Nepal, Kathmandu, Nepal \\ Corresponding author: bhusalp1@gmail.com
}

\begin{abstract}
This paper highlights the lessons of using adaptive learning in community forestry that effectively help to resolve forest based conflicts in Terai region of Nepal. The paper is based on a threeyear action research carried out in Terai. Qualitative methods including participatory rural appraisal tools and documentation of engaged action and reflections were used. Methods and tools that largely fall under adaptive learning were deployed. The field data was complemented by review of secondary data and literature on environmental history of Terai. We found that policies on land and forest in Terai for the last fifty years have induced and aggravated conflicts over access and control between state and communities and also within diverse groups of local communities. These conflicts have had serious negative impacts on sustainable management of forests and on local people's livelihoods, particularly resource poor and landless people. Centralised and bureaucratic approaches to control forest and encroachment have largely failed. Despite investing millions of Rupees in maintaining law and order in forestlands, the problem continues to worsen often at the cost of forests and local communities. We found that transferring management rights to local communities like landless and land poor in the form of community forestry (CF) has induced strong local level collective action in forest management and supported local livelihoods. Moreover, adding adaptive learning, as a methodological tool to improve governance and enhance local level collective action significantly improves the benefit of CF. It implies that a major rethinking is needed in the current policies that have often led to hostile relationships with the local inhabitants- particularly the illegal settlers. Instead, transferring forest rights to local communities and supporting them through technical aspects of forest management will strengthen local initiatives towards sustainable management of forests.
\end{abstract}

Key words: Collective action, community forestry, illegal settlements, tenure, Terai

\section{INTRODUCTION}

Forest conflicts between the state and communities, and also at the local level, are widespread in Nepal (Shrestha and Conway 1996; Pravat and Humpreys 2013). Most of these conflicts have resulted from insecure rights of the forest dependent people and poor forest governance in the context of heavy reliance of the poor on forest resources (Shrestha and Conway 1996). Conflict over forest land has been even stronger than conflict over the access and use of forest products. Due to fertile soil, rich biodiversity, dense population and accessible landscape, the forestlands in the Terai region are subject to competing use resulting in conflicts. As per the Department of Forest statistics, over 100 thousand hectares (ha) of public forestland is illegally occupied by individuals and institutions for settlements and farming. Accordingly, encroachment has been identified as one of the major challenge for sustainable forest management, especially in Terai.

Nepal's community forestry (CF) programme, that is often regarded as one of the most successful approaches of managing forests with positive ecological, 
economic and social outcomes (Pokharel et al. 2007; Ojha 2009; Bluffstone et al. 2015), has not been tested under aforesaid conflict situation(s). Handing over CF to illegal settlers ${ }^{1}$ is often regarded as illegitimate and therefore potential roles of CF in managing forest based conflicts are not fully explored in Terai. In this context, this paper documents and shares the experiences of the outcomes of 3-years long action research initiatives experimented with facilitating $\mathrm{CF}$ process among illegal settlers. However, the CF programme, in itself, is not sufficient; rather introduction of $\mathrm{CF}$ with specific approach to identify sources of conflicts and help in mitigating it is important. The paper presents insights and lessons on the potential role of CF complemented by adaptive learning approach to analyse the situation, collaborative planning and strengthening collective action in addressing the forest conflicts in Terai region of Nepal. Experimenting with adaptive learning within $\mathrm{CF}$ in the context of deeply entrenched conflicts on forestlands is expected to provide new insights in managing widespread conflicts in and around forests across the Terai region of Nepal.

The paper has six sections. In the next section, we briefly describe the methodology followed by an overview of the history of forest-based conflicts in Terai. In the fourth section, we present a detailed case of Janakalyan Community Forest User Group (CFUG) where the action research was carried out - its context, interventions and outcomes. We, then, discuss the potential role of CF in mitigating forest-based conflicts in Nepal's Terai drawing from our case. Finally, we conclude the paper by indicating potential policy implications.

\section{METHODOLOGY}

The research was conducted using a qualitative, interpretative method combining Participatory Action Research (PAR), adaptive learning, secondary data and literature review. Contrary to previous studies in Terai forest governance (Ojha 2007; Pravat and Humpreys 2013), this study draws heavily from PAR conducted as a part of three year action research from 2014 January to 2016 December in three research sites in Nawalparasi. The findings are based on the intensive field actions, documentation and analysis enriched by secondary data on forest and landlessness, and literature on conflicts in and around forestlands. PAR and adaptive learning process in three sites namely in Janakalyan CFUG in Shivamandir, Ankur Adarsa CFUG in Danda and Bartandi CFUG in Rajahar village development committee (VDC) of Nawalparasi district form the core information however the paper is built on the primary analysis of one specific case from Janakalyan CFUG. Starting with initial memorandum of understanding with the CFUGs, the research developed through a series of step-by-step process that involves a dialogic process in generating data, collective analysis and synthesis. The intensive fieldwork at specific site level, reflective workshops at sub-district level, stakeholder workshop at district level, and policy dialogue at national level were the key steps adopted. Similarly, at the site level, different tools for action and

\footnotetext{
${ }^{1}$ In our case, illegal settlers are the people who are largely landless and in the present context the land that they are holding is encroached forest land and has not recognised by the government or by the present laws (are not legalized yet).
} 
documentation were used: observations of meetings and workshops, document analysis, key informants' interviews, focus group discussions, transect walk of forestlands, and use of secondary data on illegal activities cases. The field-based data is complemented by information on forest encroachment at the district level and the analysis of district level CF performance in addressing the forest-landless conflicts. Similarly, the interviews with key forestry and land management stakeholders were also taken along with the review of national government initiatives to resolve the landless conflicts. The core of the analysis builds specific site level case from Janakalyan CFUG. It describes the conflict (state-community, between communities, and within communities) around forest and forestlands caused by landless induced forest encroachment and illegal logging.

\section{ILLEGAL SETTLEMENT AND FOREST CONFLICTS IN TERAI}

The Terai occupies 14.2 per cent of Nepal. According to the FRA/DFRS (2014), forests covered 20.41 per cent $(411,580$ ha) of the Terai. Out of the total forests in the Terai, 76.45 per cent lie outside of the Protected Areas (PAs) ${ }^{2}, 16.97$ per cent inside PAs, and the remaining 6.58 per cent inside the buffer zones. Forests in the Terai, however, have been in a state of decline for decades due to a number of reasons.

Forests in the Terai have been battlefields since the 1950s where forest conservation efforts and occupying land for agriculture and settlement have been in continuous tussle (Shrestha and Conway 1996). The annual rate of forest decline in Terai between 1991 and 2010 was 0.40 per cent whilst it rose to 0.44 per cent between the years 2001 and 2010 (FRA/DFRS 2014). The demand for land has been particularly high in the Terai region because of its flat and fertile terrain, and its easy and open accessibility to the Indian borders. In order to meet this demand, people encroach and illegally settle in the forests.

An analysis of forest cover loss in the Terai between 1991 and 2010/11 showed that the major reason for forest cover loss was conversion to agriculture/cultivation (62\%). It has been estimated that more than 570,000 ha. of forestland in the Terai have been encroached from 1964 to 1991 with 380,000 ha. of such encroached forest having been converted for the purposes of agriculture and infrastructure development (Baral and Poudel 2016). Other factors included river-beds owing to changes in river courses $(15 \%)$, Other Wooded Land (OWL) (4\%), grassland (4\%), and others e.g. barren land (15\%) (FRA/DFRS 2014). As aforesaid, illegal settlement or forest encroachment has emerged as one of the important drivers of forest degradation in Nepal, particularly in the Terai region. As of 2015/16, 94,871.67 ha of forestland in Nepal were reported to be encroached with nine out of the ten districts (Table 1) with highest levels of encroachment taking place in the Terai.

\footnotetext{
${ }^{2}$ The Terai Arc Landscape (TAL) which stretches from the Bagmati River in the East to the Mahakali River in the West has six Protected Areas (PAs)-three national parks, two wildlife reserves (WRs) and one conservation area-and their buffer zones, which cover 5,538 sq. $\mathrm{km}$.
} 
Table 1. Level of Encroachment of Forestland

\begin{tabular}{lllll}
\hline S.N. & Districts & $\begin{array}{l}\text { Total forest area } \\
\text { (in ha) }\end{array}$ & $\begin{array}{l}\text { Encroached area } \\
\text { (in ha.) }\end{array}$ & $\begin{array}{l}\text { \% of forest } \\
\text { encroached }\end{array}$ \\
\hline 1. & Kailali & 198,239 & $21,484.00$ & 10.84 \\
2. & Kapilvastu & 59,025 & $10,636.00$ & 18.02 \\
3. & Rupandehi & 25,105 & $8,346.00$ & 33.25 \\
4. & Udaypur & 149,125 & $7,438.00$ & 5.00 \\
5. & Nawalparasi & 103,593 & $6,758.50$ & 6.52 \\
6. & Kanchanpur & 77,630 & $6,290.00$ & 8.10 \\
7. & Rautahat & 25,874 & $2,874.94$ & 11.11 \\
8. & Dang & 192,682 & $2,693.05$ & 1.39 \\
9. & Jhapa & 17,349 & $2,065.49$ & 11.90 \\
10. & Salyan & 121,258 & $1,851.75$ & 1.53 \\
\hline
\end{tabular}

Source: FRA/DFRS (2014); Baral and Poudel (2016)

As Table1 depicts, forestland encroachment is a rapidly occurring phenomenon that has led to decline in forest in the Terai. A number of reasons could be attributed for high levels of forestland encroachment particularly in the Terai.

First, as aforementioned, due to fertile soil, rich biodiversity, and accessible landscape, the forestlands in the Terai region have been subject to competing use that have resulted in direct conflicts between conservation efforts and agricultural expansion. Second, land has always held a significant social, economic and political importance in Nepal. Although patterns associated with land tenure have evolved over time, access to land remains a key basis of social, economic and political status for the Nepali population, especially in the rural context (Upreti 2004; Adhikari and Chatfield 2008). Such value associated with land ownership has made it a highly contentious issue. Third, forest encroachment has gained momentum in the Terai as a result of political backing. For example, within the last 10 years, 3,000 ha. of forestland in Attariya, Kailali district has been encroached by the people with the backing of local political parties (Panta 2018). Fourth, the fast growing population of the Terai, internal migration, increasing landlessness and food scarcity, rising value of land, and weak forest governance are contributing to forestland encroachment. The population of the Terai has been increasing over time. In 2010/11, it constituted of 50.3 per cent of the total population of Nepal (CBS 2010). One of the major contributing factors to this increasing trend in the population of Terai is migration. People migrate from the Mountains and Hills to the Terai for a number of reasons such as resettlement program(s) (Conwayetal.2000), availability of fertile arable lands, better employment opportunities and (perceived) better access 
to basic infrastructures of development like education, transportation, health and electricity. The land issue is one of the most important and complex issues in the Terai region. Land ownership remains highly inequitable in Terai which is shown by the degree of landlessness in Nepal's ecological belts from 1995/96 to 2010/11 (Table 2).

Table 2. Increasing Trend of Landlessness from $1995 / 96$ to $2010 / 11$

\begin{tabular}{llll}
\hline & \multicolumn{3}{c}{$\begin{array}{c}\text { Agricultural holdings } \\
\text { with no land }\end{array}$} \\
& $1995 / 96$ & 2003/04 & 2010/11 \\
\hline Mountain & 1.96 & 3.1 & 9.2 \\
Hills & 12.03 & 20.2 & 25 \\
Terai & 24.41 & 27.6 & 30 \\
\hline
\end{tabular}

Source: CBS 1995; CBS 2003; and CBS 2010

It can be inferred from Table 2 that the incidence of agricultural households without land has been the highest in Terai since 1995/96 when compared to the other ecological belts of Nepal. For 30 per cent of the households in the Terai region to not have any land in 2010/11 is a serious problem. This problem of landlessness is one of the major reasons as to why $\mathrm{HHs}$ clear forestlands and settle illegally.

Despite several policies and measures undertaken by the Government of Nepal $(\mathrm{GoN})$ in halting forest decline in the Terai, the problem still prevails. One of such measures being undertaken was the management of the Terai forests under different management regimes namely, i) government-managed forest, ii) collaborative forest management (CFM), iii) community forest, iv) leasehold forest (LF), v) religious forest, vi) PAs, vii) buffer zone community forest, and viii) private forest. An examination by FRA/ DFRS (2014) of 15 types of natural and anthropogenic disturbances ${ }^{4}$ in 175 forested sub-plots with some of the aforementioned known management regimes (namely government forest, PAs, buffer zone CFs, $\mathrm{CF}, \mathrm{CFM}$ and private forest) found that the Terai forests were highly disturbed by livestock grazing, tree cutting, sapling and pole cutting, and forest fires. In addition to these forest disturbances, forest encroachment (and illegal settlement) in the Terai was identified as another important contributor. Encroachment accounted for 5 per cent of Terai forest disturbance (FRA/DFRS 2014). Another attempt by the GoN in halting forest encroachment is through the Department of Forest's (DoF) "National Forest Development and Management Programme". This programme is particularly aimed at halting encroachment in the Terai. Through this initiative, the GoN aims to address the problem of encroachment and illegal settlement through the eviction of illegal settlers and subsequent provision of alternative settlement options. As of 2015/16, only 1613 ha. (out of targeted

\footnotetext{
${ }^{3}$ As per the definition used in the Nepal Living Standards Survey conducted by the Central Bureau of Statistics (CBS), agricultural holdings are grouped into two categories: land holdings and holdings with no land. Holdings with land are those cultivating at least 0.013 hectares (1458 sqft or $8 \mathrm{dhur}$ ) in the case of Terai and at least 0.0127 hectares (1369 sqft or 4 aana) in the case of Hills and Mountains during an agricultural year. Holdings with no land, on the other hand, are those with two or more cattle (or the equivalent of other livestock and poultry birds) and operating less than 0.013 hectares of land for agricultural purposes.

${ }^{4}$ The 15 natural and anthropogenic forest disturbances identified for the FRA/DFRS (2014) study were bush cutting, encroachment; forest fire; insect attack; landslide; lathra cutting; litter picking; livestock grazing; lopping; plant disease; plant parasite; tree cutting; wildlife grazing; wind, storm, hails (frozen rain); and other human induced disturbances.
} 
2460 ha. of encroached forestlands) have been reclaimed. Budgets have been allocated by the DoF for the resettlement of such illegal occupants. However, lack of clarity with regard to how and where they will be resettled has invited uncertainty and angst not only amongst the illegal settlers but also those who are already residing in the Terai. Hence, incidents of conflicts have arisen as a result.

This exemplifies the failure of the GoN's approach in managing forests of the Terai including curbing its illegal settlement. Furthermore, attempts to control illegal settlement of Terai forests have not been completely successful because of the informal support from politicians who aim to increase their respective voting blocs. In this regard, the politicians tend to provoke the locals in the forefront in the name of championing their rights. This often leads to conflict of interest, resulting in frequent clashes between the illegal settlers and government authorities. This gets more complicated given the locals' polarized viewpoints regarding $\mathrm{CF}$ and $\mathrm{CFM}$ in Terai (Pravat and Humphreys 2013). As a result, recent years have witnessed an intensification of forest-related conflicts between various stakeholders in Nepal, particularly between the state and local people- over the control, management and use of forests in the Terai.

Illegal settlement in the forest lands of the Terai has had multiple consequences. As noted earlier, a significant portion of the forests has been lost because of illegal occupancy. In addition to decline in the forested area in Terai due to encroachment, it has also invited a series of disputes and conflicts in the communities. Given the Terai's complex socio-ecological context compounded by the incidence of poverty, landlessness, uneven pattern of forest resource and population distribution (proximate and distant users), high rates of migration, and rising ethnic tensions, it is bound to be a challenge to halt illegal settlement in Terai while avoiding multi-level conflicts. Moreover, loss of forests implies degraded ecosystems and biodiversity. In other words, illegal settlement in the forests of Terai has led to a lose-lose situation for both forests as well as the people.

\section{POLICY RESPONSES AND ITS EFFECTIVENESS}

For years, the GoN has undertaken a number of initiatives to help address the problem of illegal settlement in the forestlands of Nepal, particularly the Terai. Articles and clauses in a number of Policies, Acts, Regulations, Strategies, and Action plans with clearly stated consequences and ramifications for illegal settlement are already present. For instance, Clauses 3, 16, 49 (A), and 50 (2) of the Forest Act (1993) clearly state and discuss about the legal implications for illegal forest settlement and settlers (HMG/N 1993). Similarly, Clause 5 (B and C) of the National Parks and Wildlife Conservation Act (1973) stipulates clear restrictions to settlement and illegal activities related with settlement inside PAs, wildlife reserves (WRs) and the buffer zones. Similarly, rules within this Act such as the National Parks and Wildlife Conservation Rules (1975), Wildlife Reserve Rules (1977), and Buffer Zone Management Rules (1996) also prohibit illegal settlement in forestlands (HMG/N 1973). In addition, measures to control and prohibit illegal settlement in forestlands are also mentioned in Forest 
Policy (2015), Forestry Sector Strategy (2016-2025), National Biodiversity Strategy and Action Plan (2014-2020), and the Fourteenth Plan (2016/17-2020/21). The Forest Encroachment Control Strategy (2012) has adopted a number of strategies to control forestland encroachment. The DoF has been making efforts to control forest encroachment and conserve forest resources under its jurisdiction by enforcing existing aforementioned legislation through the district forest offices (DFOs) under it. However, figures and data pertaining to continued forest encroachment despite these central government measures is a clear indication of a failed bureaucratic approach to forest management and illegal settlement within forestlands in the country.

For instance, since the 1960s, the government has been struggling to stop encroachment despite criminalizing it, increasing surveillance, and carrying out frequent evictions. Table 3 below shows the government target(s) and the budget(s) being allocated to these campaigns.

Table 3: Status of Eviction from Forest and Associated Costs

\begin{tabular}{llll}
\hline Fiscal Year & $\begin{array}{l}\text { Target Eviction } \\
\text { area (in ha) }\end{array}$ & $\begin{array}{l}\text { Evicted Area } \\
\text { (in ha) }\end{array}$ & $\begin{array}{l}\text { Budget Allocated } \\
\text { (In NRs.) }\end{array}$ \\
\hline 2014 & 985 & 638 & 2940000 \\
2013 & 750 & 648 & 3000000 \\
2012 & 316 & 790 & 948000 \\
2015 & 725 & 680 & 2900000 \\
2016 & 575 & 434.12 & 2540000 \\
\hline
\end{tabular}

Source: MoFSC (2016)

There is a huge cost associated with strengthening surveillance and evicting the encroachers. As shown in Table 3 above, NRs. 3 million is required to evict 600 hectares of the encroached land. As there is almost 100 thousand hectares of encroached land, eviction is not an optionor at least it is a very costly affair. Similarly, lack of human resources at the DFO further questions the current government approach. An Assistant Forest Officer (AFO) in Nawalparasi opined,

To evacuate 10-15 landless households (HHs), it takes around two months and an investment of NRs. 100 thousand. The planning process is quite long and needs a close collaboration with the Chief District Officer (CDO), police, local political parties, and media-not to mention, local political parties often exert strong resistance to such plans.

Similarly, the government's approach in the formation of 'landless problem solving commission' and land distribution shows limited scope in addressing ongoing encroachment trend in the Terai. 12 different commissions have been formed since 1995 and half of them dissolved before they could complete their studies. These commissions so far have distributed land entitlement certificates to $154,853 \mathrm{HHs}$ while current landless $\mathrm{HHs}$ accounts for 
more than a million. The poor performance of the 'Landless Commissions' is mainly accounted to their alignment with particular political parties, corruption, and short-term working scope among others. Thus, the resolution of encroachment problem in Nepal has largely failed due to illicit support of political parties to land seekers, lack of alternative livelihoods, low capacity of forest authorities, high costs of law enforcement, and importantly, the weak authority of the state (Regmi et al. 2015).

\section{THE CASE OF JANAKALYAN COMMUNITY FOREST}

Located in central Terai of the Kawasoti municipality of Nawalparasi district in the southern part of the Mahabharat range and 4 kilometers north from the east-west highway, Janakalyan CF was legally established in 2014 with 182 ha of forest and $287 \mathrm{HHs}$ as its members. It is dominant Sal (Shorea robusta) forest and can fetch high market value. The CF members are largely landless (86\% $\mathrm{HHs})$, socio-economically marginalised and have migrated to this place from different parts of the hills. Only a portion of people hold productive farmland $(14 \% \mathrm{HHs})$ and earn from agriculture and they are traditionally considered to be high caste and are active in the local political and intellectual domains. The village is located in the middle of the forest and almost 80 per cent of landless households used to rely on illegal collection of timber and fuelwood. Consequently, the forests were severely degraded and the society was crippled with illegal activities, frequent arrests by the forest authorities and internal disputes between various groups.

While few leaders from 1996 were trying to protect the forest by forming informal forest user committee to foster sustainable forest management and control illegal activities, they were challenged both by the authorities as well as by the locals who were benefitting by the status-quo. The few leaders among landholders, landless elites ${ }^{5}$ and politically affiliated groups repeatedly occupied the position and enjoyed the benefits keeping aloof the large population that heavily interacted with forest for daily livelihood (see Table 5). Consequently, it decreased the effectiveness and accountability towards leadership as the leaders had no compliance towards rules and regulations and the forest authorities were unable to monitor and control illegal activities. Hence, people enjoyed free access to forest in the region. More importantly, denying access to forest in many cases has further triggered burgeoning conflict between the landless groups, forest authorities and local residents which often results in forest degradation.

Realizing this pertinent conflict in and around forest management and landlessness, we embarked with an action research initiative to help understand and resolve the conflict among different groups including the forest authorities. We initiated a dialogue with Janakalyan $\mathrm{CF}$ leaders and reviewed the problem and realized its seriousness. Then we reached to an agreement to jointly work by employing an adaptive learning approach to initiate dialogue with all

\footnotetext{
${ }^{5}$ Landless elites are the people who are landless but are either in the leadership, or could influence the decision making process and have strong political support.
} 
local inhabitants, forest authorities and neighbouring communities with regard to the conflict issues. Accordingly, we formed an Adaptive Learning Group ${ }^{6}$ (ALG) comprising of 20 members representing village leaders, forest authorities, the Federation of Community Forest User Nepal (FECOFUN) and the research team. We then developed a plan to assess environmental change, Tole meeting with all settlers, reflective workshops, meeting(s) with forest authorities, and development of Operational Plan (OP) and approaching the DFO.

\section{History of Settlement and Conflicts}

Until 1951, much of Nawalparasi area was covered with forest, and only some of the southern part of the district was sparsely populated by the Tharu and Madhesi people. Then King Mahendra in the 1960 s invited the non-resident Nepalese to settle on cleared the Terai forestland (Ghimire 1992). Similarly, the construction of the east west highway attracted settlement, agriculture and high population along the highway with massive infrastructural development at the expense of forest land. This encouraged landless and other people from mountain to resettle in the Terai by clearing the dense forest. The settlement in and around Janakalyan CFUG was started in the early 1970s. Majority of the population here are hill-migrants who were flood victims/landless victims and few of them migrated from surrounding districts. The settlement is dominated by Dalits and Janajatis who primarily depend on forest as the means for living and a sense of security and belongingness in a community.
The continued forest land encroachment, illegal activities around timber and unsustainable collection of firewood has been the primary causes of conflicts between the community and forest authority in Janakalyan CF. This has further prolonged due to increased intercommunity conflicts on access and control of forest resources including leadership and benefits sharing. The conflict was between users: the landless and landowning elites on the access and control of forest resources and for the on the leadership position. Similarly, the issue on the 8.5 ha grassland on the boundary has amplified the conflict by creating barging space for the landless elites and few land holders. All these conflict-related issues have contributed to the delay in the forest handover process.

There was conflict between CFUG and forest authorities in the forest handover and management process. Usually, forest authorities used to be reluctant in handing over forest management rights to the landless people. The major reason behind it is the stereotyping of landless as encroachers and illegal loggers. Roughly, there are around 3000 proposed CFs in Terai which are struggling for handover and most of the CFs is embroiled around the issue on landlessness and forest encroachment (interview with forest officials, Nawalparasi DFO). In Nawalparasi district, there are around 70 proposed CFs. Janakalyan and neighboring Maharaja and Buddha CFUGs also had similar issues and struggled for around 18 years to get forest handover from $\mathrm{DFO}$ (see Table 4). Out of 32 CFUGs under Maharaja Elaka Forest office in Kawasoti area, 13 CFUGs are still struggling for

${ }^{6}$ Adaptive Learning Group (ALG) is the learning forums where the Non-PAR CBOs learns from the experiences and research outputs sharing from PAR CBOs (Research sites). 
handover and most of these CFUGs suffer from forest encroachment by landless, boundary conflicts and illegal logging.

The Assistant forest officer in Kawasoti shared,

There are many CFUGs which are yet to be handed over and some of them are in the process of being handed over as well. The major challenge we see is the internal conflict within the CFUGs on managing landless users, the management of encroached forest area and boundary delineation. Similarly, the control of illegal logging has been the major challenge for us.

Table 4: An Example of Forest Handover Attempts and Causes of Failure in Janakalyan CFUG

\begin{tabular}{|c|c|c|}
\hline $\begin{array}{l}\text { Forest handover } \\
\text { attempts }\end{array}$ & Process & Causes of failure \\
\hline $\begin{array}{l}\text { In } 1996 \\
\text { (first forest } \\
\text { management } \\
\text { committee } \\
\text { formed) }\end{array}$ & $\begin{array}{l}\text { Decided by } \\
\text { the executive } \\
\text { committee (EC) } \\
\text { but no further } \\
\text { process }\end{array}$ & $\begin{array}{l}\text { - No interest of leaders on further process of } \\
\text { handover } \\
\text { - Leaders focused on benefits from illegal timber } \\
\text { harvesting and distribution }\end{array}$ \\
\hline $\begin{array}{l}\text { In } 1999 \text { ( } 4^{\text {th }} \\
\text { informal EC) }\end{array}$ & $\begin{array}{l}\text { - Decided by the } \\
\text { EC } \\
\text { - The Constitution } \\
\text { was made and } \\
\text { submitted to the } \\
\text { DFO } \\
\text { - Failed to register }\end{array}$ & $\begin{array}{l}\text { - Some of the leaders who were getting personal } \\
\text { benefits from illegal activities surrounding } \\
\text { timber and land encroachment stopped the } \\
\text { handover process } \\
\text { - Forest encroachment by landless as an illegal } \\
\text { activity } \\
\text { - Conflict claim on } 8.5 \text { ha grassland on boundary } \\
\text { within two villages } \\
\text { - Some forest officials also used to get enjoy } \\
\text { benefits from illegal logging }\end{array}$ \\
\hline $\begin{array}{l}\text { In } 2005\left(7^{\text {th }}\right. \\
\text { informal EC) }\end{array}$ & $\begin{array}{l}\text { - Decided by the } \\
\text { EC } \\
\text { - Conducted } \\
\text { forest survey, } \\
\text { boundary } \\
\text { delineation but } \\
\text { didn't carry out } \\
\text { other processes }\end{array}$ & $\begin{array}{l}\text { - No support from landless community } \\
\text { - Landless had the fear that after handover, their } \\
\text { encroached land would come under CF } \\
\text { - Some landholders and landless elites who } \\
\text { benefitted through illegal logging didn't want } \\
\text { forest to be handed over because after CF } \\
\text { handover, such activities can't be continued } \\
\text { - Conflict due to claims on 8.5ha grassland lying } \\
\text { on the boundary within two villages }\end{array}$ \\
\hline $\begin{array}{l}\text { In } 2008 \text { ( } 9^{\text {th }} \\
\text { informal EC) }\end{array}$ & $\begin{array}{l}\text { - Made the } \\
\text { constitution but } \\
\text { didn't proceed } \\
\text { further }\end{array}$ & $\begin{array}{l}\text { - Conflict due to claims on } 8.5 \text { ha grassland lying } \\
\text { on boundary within two villages } \\
\text { - Massive illegal logging and collection of } \\
\text { firewood } \\
\text { - Encroached land would merge to CF after } \\
\text { handover } \\
\text { - Forest authority was reluctant in handing over } \\
\text { CF in forest dominated by the landless }\end{array}$ \\
\hline
\end{tabular}


Similarly, it was always a burden for CF under CF as in these land because they leaders to manage illegal activities as they either have their houses there or are using had no formal rights in doing so, which it for agriculture. Similarly, illegal logging forest authority wanted them to execute. and poaching issues always becomes the The government always wants all the bargaining point for the authorities for not illegally occupied land under CFUG transferring the forest management rights which is the part of CF. However, users are not ready to include the occupied land to community.

Table 5: Different Groups of People and Benefits they Receive from Forest before Forest Handover

Different Groups of people Benefits from Forest Management

Landless elites

- were in leadership position (EC member), influenced decision for their benefits around timber, forest encroachment

- had encroached forest land and did cultivation, even did land auction

- insisted their relatives from hills and other places to migrate and encroach more land

Landless or land poor

Local political leaders

Landholders
- forest encroachment for agriculture and house construction

- sale of firewood for subsistence livelihood

- collection of fodder, leaf litter, different food products and vegetables

- were in leadership position (EC member) and gained benefits such as timber for construction of houses, as well as income

- used landless as a vote bank to support their acts of forest encroachment

- benefits including timber for construction of houses

- were in leadership position (EC member)

- benefits from grassland within forest area 
Similarly, there was conflict between landless members and land owing members in leadership as the latter did not want landless members to be a part of their EC. Similarly, inequitable benefit sharing and non-transparent economic transactions had seriously weakened forest governance resulting in dissatisfaction among members. In particular, conflicts between two villages over 8.5 ha of grasslands was critical, which at times used to take a violent turn.

During the handover process, there was a serious conflict between the landless and land owing group in claiming the handover benefits. The EC in which majority of the members were landless were leading forest handover process. However, the land owning groups were against this process. They went to meet the delegation at the DFO office as well as the FECOFUN district chapter to stop the ongoing forest handover process claiming the process was illegal and they (the landless) are not the actual inhabitants of that place.

For the last 15 years, the land owning groups were in charge of decision making and have enjoyed access to use and use of the larger portion of the resources. However, now they were not ready to give up the whole management rights to landless leaders and users. They thought forest registration and handover process would shift the resource management authority to landless people which will decrease their social height in the community. Thus, this halted the forest handover process and created huge social differentiation among the landless and land owing group.
On 11 December 2014, during informal meeting at a tea shop at Janakalyan CFUG, one of the members from a land owning group who was against EC during forest handover process shared::

The landless-dominated EC has been working haphazardly; they have fired our EC members (who represent land owning groups) and have elected a majority group who are favorable to their agenda. This has shown their negative intensions and they want to negotiate with the neighboring $C F$ regarding the grassland issues which we have been using for the last 30 years with no consultation with us. This will make the situation messy and we will no longer support them. Now, we will see how they will make the upcoming General Assembly a success!

\section{Impacts on Forest}

Encroachments by landless, timber smuggling and illegal collection of fuelwood have posed major challenges to forest management in Janakalyan CF. The forest was open access and people used to encroach forest land for settlement and agriculture. More than $80 \%$ of the $\mathrm{HHs}$ have encroached forest land for settlement and agriculture and almost $80 \%$ of the landless $\mathrm{HHs}$ used to rely on illegal collection of timber and fuelwood. This resulted in resource degradation of forest and hardship in collection of basic forest products such as fuelwood and fodder for livestock. The poorest groups were hit hard. There was serious decrease in the forest products, which was largely due to 
due to illegal activities (see Table 6). Most of the HHs shuffled from agriculture and wage labour to illegal logging and sale of firewood ${ }^{7}$. People deliberately used to set forest on fire. Illegal loggers used to collect dry leaves and put fire around the stumps to destroy its freshness in order to make it look like an old cut tree ${ }^{8}$.

\section{Community Forestry Initiatives}

On April 29, 1996, the community leader of different hamlets of Janakalyan CF conducted a series of meetings and agreed to (and formed) a 17 members informal forest management committee. This was the first committee formed through collective decision for the sustainable supply of firewood and timber. They set rules and regulation of/for the committee, developed mechanism to control illegal logging, unsustainable collection of firewood and coordination with the Elaka Forest Office on monthly activities. However, despite several efforts these committees failed to control ongoing massive illegal activities around timber and forest land encroachment. In some cases, the committees were also found to be involved in such activities.

There were altogether 11 informal committees formed within the period of 18 years (see Table 6) and none of the committee's tenure was sustained for more than two years. Among these committees, some tried to formulate a constitution and initiate the forest handover process but forest encroachment, illegal logging, and boundary conflicts and more importantly, the benefits around timber and its unfair distribution system had paralyzed the handover process. Within it, the frequent tension between the landholders and landless on leadership position and political ideology had weakened collective action over forest management. This ultimately decreased forest productivity and management activities.

${ }^{7}$ Chandra Kumar Sunar, One of the EC members, 5 June 2015

${ }^{8}$ Kabiram Bhandari, Chairman, 12 July 2014 


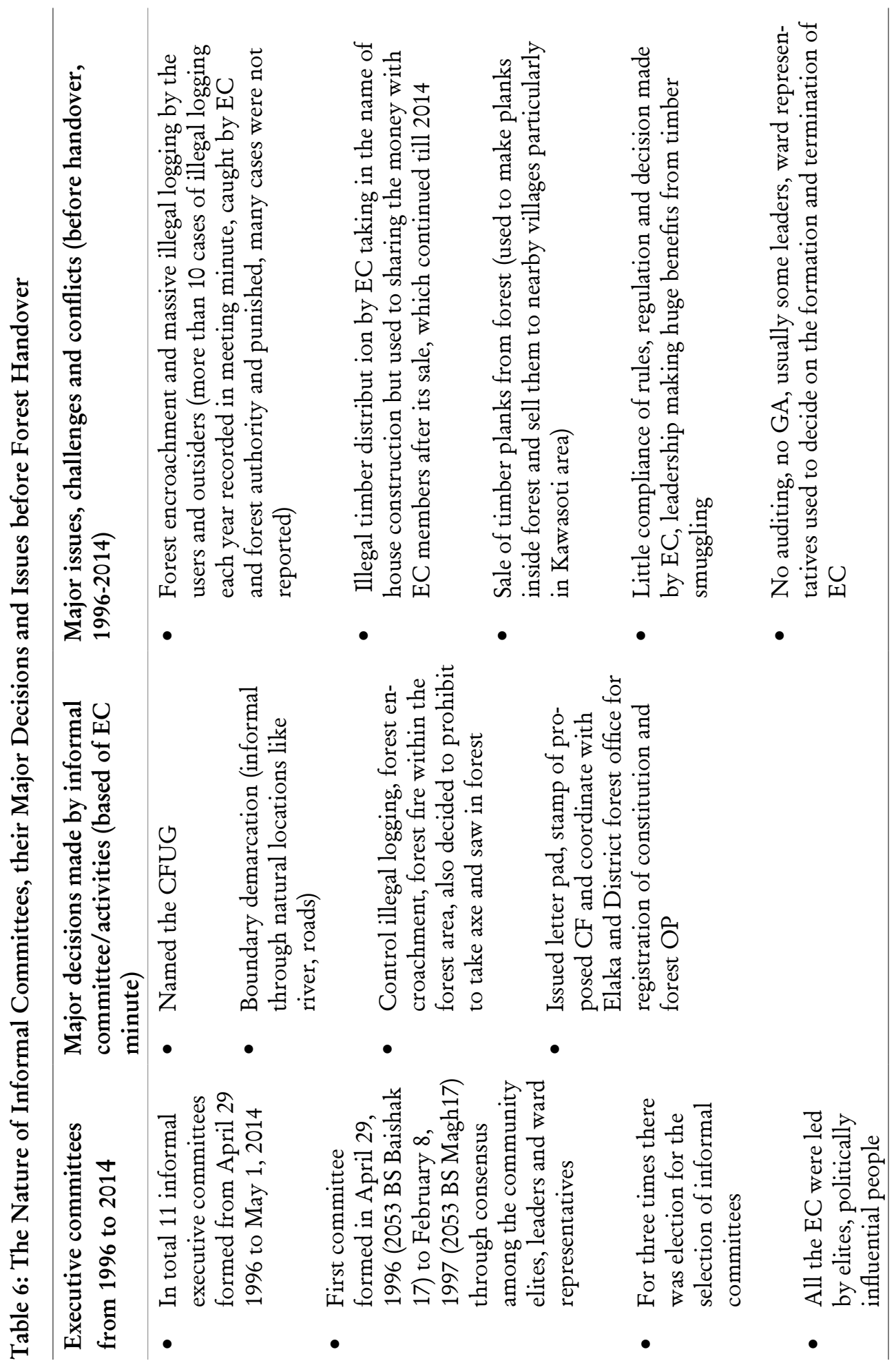




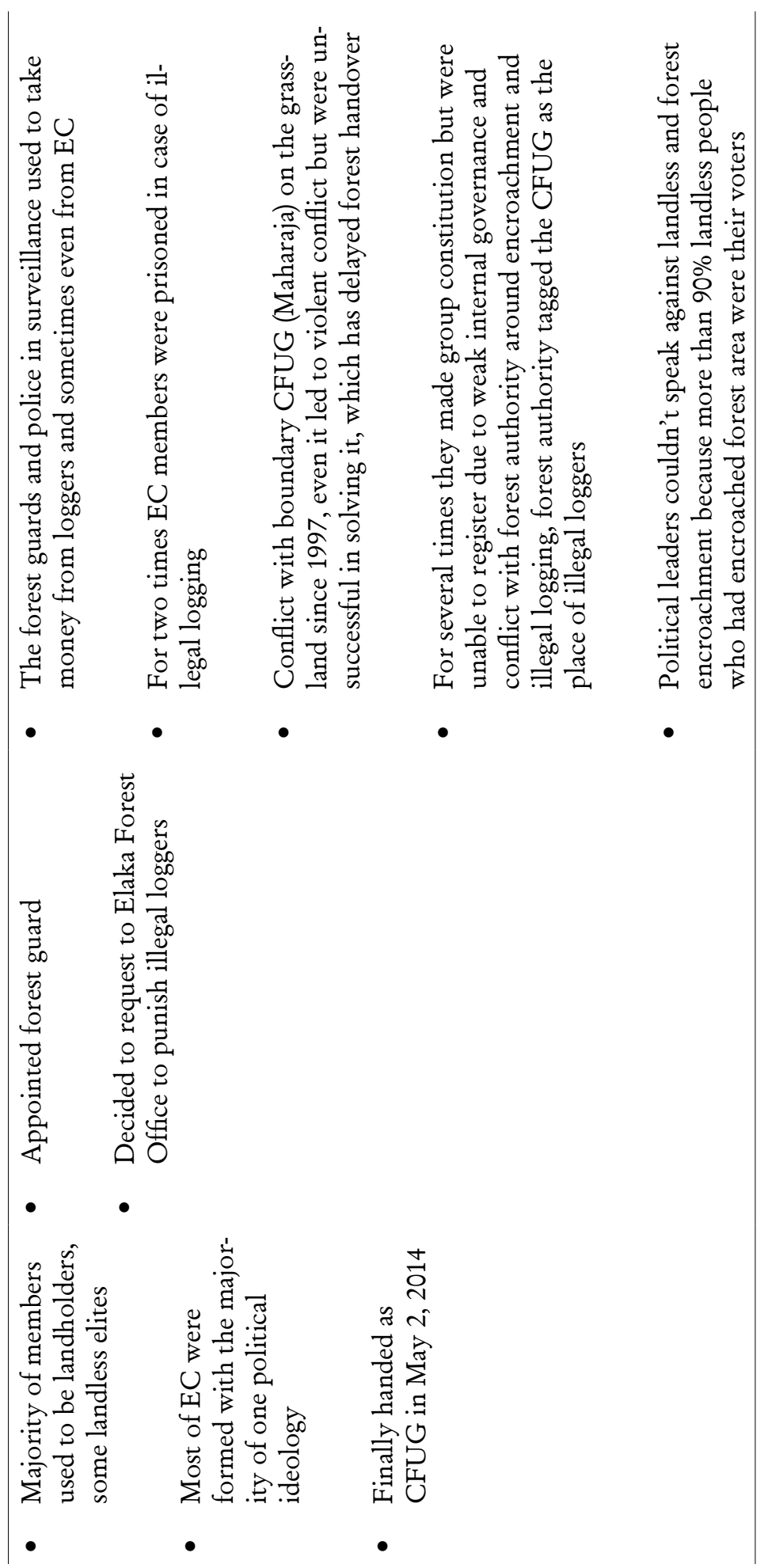




\section{Observed Outcomes}

The Janakalyan CFUG success illustrates that by recognizing and strengthening local level collective action by transferring forest tenure rights to landless can substantially reduce conflict and conserve resources. The series of meetings with the CFUG members and reviewing of the biophysical status of the forest, conflicting perceptions of various groups who were directly and indirectly benefiting within the community (see Table 5) and positions of the forest authorities, the ALG developed strategies to engage in dialogue with different conflict groups towards formalizing the CF. Accordingly series of meetings were held in all settlements and also with DFO staff. These meetings helped to consolidate commitment to form a formal CF. The border conflict with the neighbouring community was also resolved. Then, the forest OP was developed, discussed and endorsed by the GA of the community and was finally submitted to the DFO for approval. It was approved in 2014. Since then the elected body - executive committee of the CF- began to plan and implement specific activities aimed at forest conservation, harvesting, distribution along with silvicultural activities for forest improvement.

Collective efforts have reduced illegal activities (see Table 7), and some members have even agreed to let their respective occupied lands be included within the CF boundary. Since 2015, they have harvested 1400 cubic feet (cft) timber each year and sell to the users. In addition, they also provide about 12,000 quintal of firewood. Similarly, they open forest regularly for fodder and leaf litter collection. Their annual income is about NRs 1.5 million which they invest for development and livelihoods related activities. They conduct regular forest management activities (regular thinning, weeding of forest, minimized grazing and developing nursery and plantation). As a result, forest density is increasing with increment in pole size trees. They have transformed 10 ha of barren land to forest. The regular distribution of fuelwood and systematic collection of fodder and leaf litter has increased ownership among users.

The leadership has been strengthened; the CF chairman has been appointed as the leader of Elaka FECOFUN which comprised of 32 CFUGs with maximum CFs having landless issues. Similarly, the trust of users on leadership has been substantially increased and they have developed a clear short-term and long-term action plan with activities and timeline. The forest authority makes regular visits for the purpose of monitoring and has been supporting nursery and plantation activities.

Despite having success in forest management and socio-economic enhancement there are also several challenges that the CFUG leaders in Janakalyan CF should focus on. There are still some grievances among the landholders groups and with some of the landless elites as they are not in the leading position in community forest user committee. Their concern and direct observation will be on how the new EC will handle the issues of forest encroachment, illegal logging and most importantly on the proper investment of the income of the CFUGs. Similarly, addressing the increasing forest resources need of landless users in sustainable basis is another challenge which needs great effort and dedication of executive committee members. 
Table 7: Illegal Activities and Change in Collective Action after Transferring CF to Janakalyan CFUG

Illegal Activities Before forest handover

(1996-2013)
After forest handover

(2014 onwards)

They do goat and buffalo farming with the financial help from CFUG

No such cases- now they get from legal channels

Only one case in 2014 and zero in 2015 and 2016

\begin{abstract}
Timber collection and trade
\end{abstract}

Firewood collection and trade

Grazing

Forest encroachment
About $40 \%$ of $\mathrm{HHs}$ were involved directly or indirectly (among 287HHs) and on average 20 cases filed at local district forest office (each year They were usually caught and punished More than 15-20 cases daily from own users and neighboring village

Almost all landless HHs have encroached forest
No encroachment after demarcation of forest boundary

Source: Field Survey and Review of CFUG OP

\section{WHAT CAN CF OFFER?}

It is clear from the above sections that the government's policies, programs and strategies to control and manage the forest encroachers and people living close to national forests has not worked. Moreover, it has been too costly and has required continuous engagement of various stakeholders including forestry staffs which is always not possible. This had resulted in increased grievances among the local people, ultimately leading to increased gaps between forest and people and as a result, both the people and forest were losing. On one hand, for years, forest have been facing several challenges including massive decrease in forest productivity, unsustainable collection of fuelwood, fodder and illegal logging. The elites and the loggers were taking benefits from the status quo, whilst the poor were always in conflict with the authority as they faced resource scarcity. In this context, adaptive and reflective approaches have proved to be instrumental in revisiting the ongoing situation both in terms of forest loss and the difficulties that the people were facing. It opened a space for dialogue and helped to understand the pros and cons of forest handover. It urged every party to rethink on their ongoing practices and its consequences, and finally convinced them to adopt new pathways. 
It has been clear from the example of Janakalyan CFUG that the formal transfer of $\mathrm{CF}$ rights and support from authorities and other agencies has helped to induce collective action that resulted in a win-win situation. The forest user group- once rife with a whole range of forest crimes- has now turned into one of the most successful $\mathrm{CFs}$ and is appreciated by the authorities, neighboring CFUGs and also by its own members. Since long, it was an open access forest with illegal logging, poaching and unsustainable collection of fuelwood. They had not been able to claim forest management rights due to weak internal governance and dispute with neighboring communities. Upon going through the PAR process, analyzing the biophysical and legal aspects, and with improved capacity building activities, the group now has received formal forest management rights, has resolved its conflicts with the neighboring CFs and has established legitimate leadership. The CFUG, as a local natural resource institution, has provided a good platform for experimentation, innovation and negotiation.

Enhancing coordination and cooperation amongst government law enforcement agencies, civil societies, forest user groups, and the locals in general is pivotal to control illegal harvest and trade of timber and other forest products, forest area encroachment, and wildlife crimes. The tenure rights devolution in the Nepalese context in the form of $\mathrm{CF}$ has proven that local user groups can effectively conserve the forests while ensuring that illegal settlement is controlled. Moreover, the importance of the adaptive learning approach in the management of conflicts and natural resources, as depicted by the case of the Janakalyan $\mathrm{CF}$, cannot be undermined. A more adaptive approach informed by collective analysis of specific socio-ecological contexts would help to make decisions that lead to winwin outcomes. Such adaptive learning approach, as shown by the case of the Janakalyan CFUG, is not only useful in mitigating conflicts regarding management of natural resources but is also invaluable in reaching a consensus about the best way forward to managing forests in the Terai. The approach can also be instrumental in instilling practices of open and experimental approach from the DFO that promotes local leadership in addressing issues related to illegal settlement in the Terai. In this context, community forestry as a strong local institution can foster a win-win situation by involving landless in forest management and ensuring their collective action. It can fulfill the twin objective of forest conservation and livelihood support of landless poor.

\section{CONCLUSION AND POLICY IMPLICATIONS}

The paper demonstrated that forests of Nepal's Terai region have historically faced chronic conflicts between illegal settlers and forest authorities. It described that despite diverse policy responses including stringent actions against illegal settlers on one hand to distribution of land titles to thousands of identified landless people on the other, the problem persisted. Because of the deep rooted antagonistic relations and complete mistrust between illegal settlers and forest authorities, the settlers were largely excluded from managing forests. As a result, both the settlers and the forest suffered as indicated by the continuous forest loss in Terai while rest of the region has gained forest cover (FRA/DFRS 2014). 
The case of Janakalyan clearly shows the potential role of $\mathrm{CF}$ in transforming conflict into cooperation so that the situation can be changed from a loselose game to a win-win one. Reduced illegal logging, poaching, deliberate forest fires, unsustainable harvesting of other forest products appears promising. These changes were possible due to increased feeling of ownership among the illegal settlers, increased collective actions in guarding, self-discipline for responsible use, rule compliance, and additional investment in plantation, protection and other silvicultural activities. Formal handover of CF that officially recognized local stewardship over forests and ensured their access to benefits was central to these changes. Moreover, moral and technical support from forest officials and outside agencies such as the research team also became instrumental in mobilizing people, developing leadership and gaining a sense of satisfaction.

The message is clear. Strong, clear and comprehensive tenure security along with supportive services can strengthen collective actions around forests that can potentially transform conflicts into cooperation. Formal recognition of their roles and assurance of their benefits can significantly change people's behavior that is badly needed in the management of Terai forest. The paper provides stark messages to the policy makers and practitioners that recognizing rights and providing support will be much more effective than the conventional approach to separating illegal settlers from forests. The new suggested approach is not only cost effective, but also helps promote forestry for prosperity by inducing a win-win situation between forests and illegal settlers in many parts of forests in Nepal.

\section{ACKNOWLEDGEMENTS}

This paper is based on research conducted under the Community-based Adaptive Learning in management of Conflicts and Natural Resources in Bangladesh and Nepal (CALCNR) project. The project was supported by the Netherlands Organisation for Scientific Research (NWO) grant no. W 07.68.2012.424 with funding from the United Kingdom Department for International Development (DFID). We are grateful to our colleagues and the leaders and members of all of the participating CFUGs, FECOFUN and anonymous reviewers.

\section{REFERENCES}

Adhikari, C. and Chatfield, P. 2008. The Role Land Reform in Reducing Poverty Across Nepal. A paper submitted for Third Annual Himalayan Policy Research Conference, Nepal Study Center, Madison, USA.

Baral, S.R. and Poudel, G. 2016. Forest Encroachment Management: Current Situation, Challenges and Possible Ways Forward (Nepali text). In: Department of Forest. Hamro Ban (Yearly Publication of the Department of Forest) (F.Y. 2016). Kathmandu: Ministry of Forest and Soil Conservation, p. 68-78.

Bluffstone, R.A., Somanathan, E., Jha, P., Luintel, H., Bista, R., Paudel, N.S. and Adhikari, B. 2015. Does Collective Action Sequester Carbon? The Case of the Nepal Community Forestry Program. The World Bank, Washington DC, USA.

CBS. 1995. Nepal Living Standards Survey 19951996. Central Bureau of Statistics, National Planning Commission Secretariat, Government of Nepal. Kathmandu, Nepal.

CBS. 2003. Nepal Living Standards Survey 20032004. Central Bureau of Statistics, National Planning Commission Secretariat, Government of Nepal. Kathmandu, Nepal.

CBS. 2010. Nepal Living Standards Survey 20102011. Central Bureau of Statistics, National Planning Commission Secretariat, Government of Nepal. Kathmandu, Nepal. 
Conway, D., Bhattarai, K. and Shrestha, N. R. 2000. Population-environment Relations at the Forested Frontier of Nepal: Tharu and Pahari Survival Strategies in Bardiya. Applied Geography, 20: 221-242.

FRA/DFRS. 2014. Terai Forests of Nepal (2010-2012) Babarmahal, Kathmandu: Forest Resource Assessment Nepal Project/ Department of Forest Research and Survey.

Ghimire, K. 1992. Forest or Farm? The Politics of Poverty and Hunger in Nepal. Oxford University Press, London.

HMG/N. 1973. National Parks and Wildlife Conservation Act (1973). Department of National Park and Wildlife Conservation, Ministry of Forest and Soil Conservation, Government of Nepal.

HMG/N. 1993. Forest Act (1993). Ministry of Forest and Soil Conservation, Government of Nepal.

MoFSC. 2016. Annual Progress Report (2012-2016). Ministry of Forest and Soil Conservation, Government of Nepal.

Ojha, H.R. 2007. Engaging Bourdieu and Habermas to reframe forest governance in Nepalese Terai, $\mathrm{PhD}$ dissertation, School of Development studies, University of East Anglia, Norwich.

Ojha, H. R. 2009. Civic engagement and deliberative governance: The case of community forest user' federation Nepal. Studies in Nepali History and Society, 14: 1-31.
Panta. 2018. Illegal settlers occupy more than 25,000ha forest land in Kailali. The Kathmandu Post. Kathmandu, Nepal. http:// kathmandupost.ekantipur.com/news/2018-0213/illegal-settlers-occupy-more-than-25000haforest-land-in-kailali.html (Accessed on February 14, 2018)

Pokharel, B. K., Branney, P., Nurse, M. and Malla, Y. B. 2007. Community forestry: Conserving forests, sustaining livelihoods and strengthening democracy. Journal of Forest and Livelihood, 6: 8-19.

Pravat, P. S. and Humphreys, D. 2013. Using a multilevel approach to analyse the case of forest conflicts in the Terai, Nepal. Forest policy and economics, 33: 47-55.

Regmi, U., Bhusal. P., Bhandari, K., Karki, J. and Paudel. 2015. Landlessness and Forest Management: What Role for Community Forestry? Policy Brief-40. ForestAction Nepal, Lalitpur, Nepal.

Shrestha, N. R. and Conway, D. 1996. Ecopolitical battles at the Terai frontier of Nepal: An emerging human and environmental crisis. International Journal of Population Geography 2: 313-331.

Upreti, B. R. 2004. Relationships between resource governance and resource conflict: Nepalese experiences. Journal of Legal Pluralism, 71-100. 